\title{
Changes of Carbon Dioxide Concentrations in Classrooms: Simplified Model and Experimental Verification
}

\author{
Tomasz Teleszewski, Katarzyna Gladyszewska-Fiedoruk* \\ Bialystok University of Technology, Department of HVAC Engineering, \\ Białystok, Poland
}

Received: 20 May 2017

Accepted: 18 September 2017

\begin{abstract}
Our paper presents a simplified model of carbon dioxide concentrations in classrooms equipped with stack ventilation systems, based on experimental research. The test was conducted in six classrooms in the building of the Faculty of Civil and Environmental Engineering of Białystok University of Technology in northeastern Poland. The research included both classrooms that were not mechanically ventilated and classrooms that were ventilated by opening the windows during breaks between classes. In all classrooms, a linear increase in the concentration of carbon dioxide during the classes was observed. The increase of the concentration of carbon dioxide in spaces of this type depends mostly on the volume of and the number of persons present in the space.
\end{abstract}

Keywords: classrooms, stack ventilation, carbon dioxide, IAQ, indoor air

\section{Introduction}

The concentration of carbon dioxide in classrooms significantly influences the comfort of work. Classrooms are often equipped only with stack ventilation systems. Research on the quality of indoor air has been conducted in many countries [1-10]. Dorizas et al. [4] studied the concentration of $\mathrm{CO}_{2}$ in classrooms of elementary schools with stack ventilation systems in Athens in a warm climate area. They analyzed the correlation between the concentration of $\mathrm{CO}_{2}$ and the number of persons and the ventilation flux of stack ventilation systems. The authors concluded that in most classrooms

*e-mail: k.gladyszewska@pb.edu.pl the flow of ventilation air was satisfactory and greater than recommended by ASHRAE [11] and the WHO 2000 standard [12].

Pereira et al. [10] conducted their research in a secondary school located in a warm climate area. They analyzed temperature, humidity, and $\mathrm{CO}_{2}$ concentration. They also conducted a survey among students and found that IAQ was not noticed by the participants even though the levels were several times higher than the values specified in the standards. Almeida et al. [1] conducted research in buildings of educational institutions in a warm climate area. However, they focused on analyzing the thermal comfort parameters using surveys and concluded that using the PMV-PPD model leads to different conclusions depending on whether the research is conducted in a warm or cold climate. Numerical and experimental research on the quality of indoor air in 
Table 1. Indoor air quality classification according to the PN-EN 13779:2008 standard [18].

\begin{tabular}{|c|c|c|c|}
\hline \multirow{2}{*}{ Category } & \multirow{2}{*}{ Description } & \multicolumn{2}{|c|}{$\mathrm{CO}_{2}$-level above level of outdoor air in ppm } \\
\cline { 2 - 3 } & High indoor air quality & Typical range & Default value \\
\hline IDA1 & Medium indoor air quality & $400-600$ & 350 \\
\hline IDA2 & Moderate indoor air quality & $600-1,000$ & 500 \\
\hline IDA3 & Low indoor air quality & $>1,000$ & 800 \\
\hline IDA4 & & 1,200 \\
\hline
\end{tabular}

university classrooms equipped with stack ventilation systems were also conducted by [6-7]. The concentration of $\mathrm{CO}_{2}$ was equal to $2,400 \mathrm{ppm}$. In general, the thermal comfort was acceptable and the classrooms conformed to category C according to the EN ISO 7730:2005 standard [13].

The studies of the distribution of carbon dioxide in closed spaces that have been published so far have been based mostly on measurements performed in real conditions [14]. Due to the limited number of $\mathrm{CO}_{2}$ sensors, measurements are usually taken at several points. The research [14] has demonstrated the strongly spatial nature of the distribution of carbon dioxide. It was found that representative measurements of carbon dioxide concentrations can be performed effectively in the center of a space. Other papers [2, 15-17] present results of research on IAQ and modelling of the distribution of carbon dioxide in different spaces.

The Polish and European standard PN-EN 13779:2008 [18] defines air quality categories IDA 1-4 (Table 1). Categories IDA 1-4 are determined also based on the concentration of $\mathrm{CO}_{2}$.

The objectives of this research are to show changes in the content of carbon dioxide in classrooms equipped with stack ventilation systems and to create a simplified model for estimating carbon dioxide levels as a function of time, the number of persons, and the volume of the classroom. A linear regression for $\mathrm{CO}_{2}$ concentration depending on the time is given, with the aim of offering a very simple but accurate tool for engineers and designers involved with indoor air quality in schools. In the assumed linear approximation, the slope coefficient of the function depends on the number of students and the volume of the room, as well as the intercept of the function as the initial value of the carbon dioxide concentration in the classroom before the beginning of the class.

\section{Material and Methods}

The content of carbon dioxide in the studied classrooms was recorded with classes in progress and during breaks between lessons. During the classes, the windows were closed. Some of the classrooms were naturally ventilated through open windows before class by opening windows. The duration of the classrooms' natural ventilation by opening windows is shown in Table 2. The duration of natural ventilation through open windows before classes ranged from $3 \mathrm{~min}$ to $720 \mathrm{~min}$ (12 hours, or overnight).

At the Białystok University of Technology, lectures and classes are usually from 30 to 45 minutes long with 15-minute breaks between classes. Laboratory classes are 90 minutes long and are often interrupted for 10 minutes after the first 20 minutes. The research was conducted in the winter when in a moderate climate and when weather conditions are the most stable [19]. The average outdoor $\mathrm{CO}_{2}$ concentration during indoor measurements was $389 \mathrm{ppm}$. The measurements were performed using a Testo 435-4 recorder equipped with an IAQ probe for indoor air quality measurements located $1 \mathrm{~m}$ above the floor at 5 room points and then average values were calculated.

The precision of the Testo recorder was as follows: temperature in the range $20-50^{\circ} \mathrm{C} \pm 0.3^{\circ} \mathrm{C}$; relative humidity in the range +2 to $+98 \% \mathrm{RH}: \pm 2 \%$ $\mathrm{RH}$; carbon dioxide concentration in the range +0 to $+5,000 \mathrm{ppm} \mathrm{CO}_{2} \pm 3 \%$ at concentrations below 50 ppm; and atmospheric pressure in the range +600 to $+1,150 \mathrm{hPa}: \pm 5 \mathrm{hPa}$. Air velocity in the range +0.25 to $20 \mathrm{~m} / \mathrm{s}$ at the ventilation outlets was assessed by means of a vane measurement probe with a precision of $\pm 0.1 \mathrm{~m} / \mathrm{s}$ or $+1.5 \%$ of the measured value.

The parameters of the indoor environment were measured in accordance with the recommendations given in the literature [20]. At all times, the average temperature of the air in the classroom was maintained at $20.12^{\circ} \mathrm{C}$ and relative humidity was approximately $39 \%$.

The studied classrooms are equipped with stack ventilation systems and are located in various parts of the building of the Faculty of Civil and Environmental Engineering (Fig. 1). The common characteristic of all the studied classrooms is their fairly small volume and same height of $3 \mathrm{~m}$. The measurements were performed for a different number of students during classes lasting from 30 to 60 minutes. Table 2 shows the basic geometric characteristics of the classrooms, the number of persons present in the classroom, the average humidity, and the duration of the classes (i.e., the time of the measurement).

The only type of ventilation in the classrooms while classes were in progress was natural ventilation 
Table 2. Basic details of the studied classrooms.

\begin{tabular}{|c|c|c|c|c|c|c|c|c|}
\hline $\begin{array}{l}\text { Number of } \\
\text { measurement } \\
\text { series }\end{array}$ & Classroom & $\begin{array}{c}\text { Volume } \\
\mathrm{V}\end{array}$ & $\begin{array}{l}\text { Number of } \\
\text { persons } \\
n\end{array}$ & $\gamma=\mathrm{n} / \mathrm{V}$ & $\begin{array}{l}\text { Average } \\
\text { relative } \\
\text { humidity }\end{array}$ & $\begin{array}{c}\text { Initial } \\
\text { concentration } \\
\text { of } \mathrm{CO}_{2}\end{array}$ & $\underset{t}{\text { Time }}$ & $\begin{array}{c}\text { Time of } \\
\text { ventilation before } \\
\text { class through } \\
\text { open windows }\end{array}$ \\
\hline- & - & $\mathrm{m}^{3}$ & person & person $/ \mathrm{m}^{3}$ & $\%$ & ppm & $\min$ & $\min$ \\
\hline 1 & $\mathrm{~A}$ & 210.0 & 22 & 0.10 & 32.4 & 856 & 60 & 15 \\
\hline 2 & $\mathbf{A}$ & 210.0 & 20 & 0.10 & 34.0 & 1,100 & 40 & 5 \\
\hline 3 & B & 226.5 & 17 & 0.08 & 31.2 & 1,138 & 40 & 5 \\
\hline 4 & $\mathrm{C}$ & 318.4 & 6 & 0.02 & 20.9 & 551 & 40 & 720 \\
\hline 5 & $\mathrm{C}$ & 318.4 & 6 & 0.02 & 24.0 & 763 & 40 & 5 \\
\hline 6 & $\mathrm{D}$ & 201.8 & 16 & 0.08 & 37.5 & 1,872 & 30 & 0 \\
\hline 7 & $\mathrm{D}$ & 201.8 & 21 & 0.10 & 41.2 & 1,594 & 35 & 0 \\
\hline 8 & $\mathrm{D}$ & 201.8 & 23 & 0.11 & 36.7 & 1,070 & 35 & 5 \\
\hline 9 & $\mathrm{E}$ & 200.5 & 39 & 0.19 & 40.6 & 532 & 45 & 720 \\
\hline 10 & $\mathrm{E}$ & 200.5 & 34 & 0.17 & 47.0 & 1,649 & 20 & 0 \\
\hline 11 & $\mathrm{~F}$ & 417.0 & 43 & 0.10 & 32.0 & 1,333 & 45 & 3 \\
\hline
\end{tabular}

(stack ventilation and infiltration through gaps around doors into the large corridor). While measuring carbon dioxide concentration we measured the velocity of the air of stack ventilation in the ventilation grate using TESTO, which was equipped with an anemometer. After measuring the mean velocity of air in the ventilation grille, a flux of air of 0.44 to 0.56 change per hour was calculated. The publication was given an average of flux of air equal to 0.50 change per hour. The changed air flux inside the classrooms is definitely too small, which most likely resulted in the low quality of the indoor air in the analyzed classrooms. The measurements were performed in January, when classroom ventilation is difficult. However, performance of measurements in the winter period has certain advantages. Both daily and weekly outdoor conditions are more stable than any other season of the year and analyses do not require any corrections for differences in the outdoor conditions. Measurements were performed for from 30 to 60 minutes of the classes, in different classrooms, with

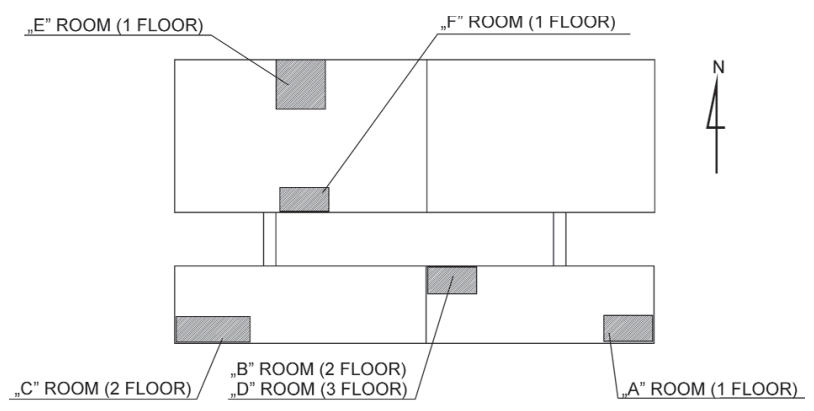

Fig. 1. Location of the classrooms in the building of the Faculty of Civil and Environmental Engineering. different numbers of persons inside them. Recording was performed every 5 minutes and the recorded value was the arithmetic average of the samples taken every 30 seconds, i.e., from 10 measurements.

\section{Results and Discussion}

Measurements of the concentration of carbon dioxide in classrooms were taken during classes and during breaks, when the classrooms were naturally ventilated through opening windows before class or not (Table 2). Fig. 2 shows the indicator of the changes in the concentration of $\mathrm{CO}_{2}$ in the classroom for an experiment with the classroom being ventilated and not being naturally ventilated by windows opening during breaks before class. The starting point (100\%) is the concentration of carbon dioxide before the classes started $(t=0)$. The percentage value of the content of carbon dioxide in the classroom increases throughout the class. During the break, when the classroom was not ventilated by opening windows before class, a small increase or stagnation of $\mathrm{CO}_{2}$ content was observed; when the classroom was ventilated through opening windows during breaks, the concentration of $\mathrm{CO}_{2}$ significantly decreased. Eventually, after two classes with ventilation of the classroom during the break, the percentage value of $\mathrm{CO}_{2}$ content increased by about $30 \%$ compared to the initial value, while when the classroom was not ventilated during the break, the $\mathrm{CO}_{2}$ concentration increased twofold. During breaks between classes the rooms were empty and were not used by teachers and students. A comparison of this data (Fig. 2) highlights the importance of ventilation of classrooms during breaks between classes. Similar results related to 


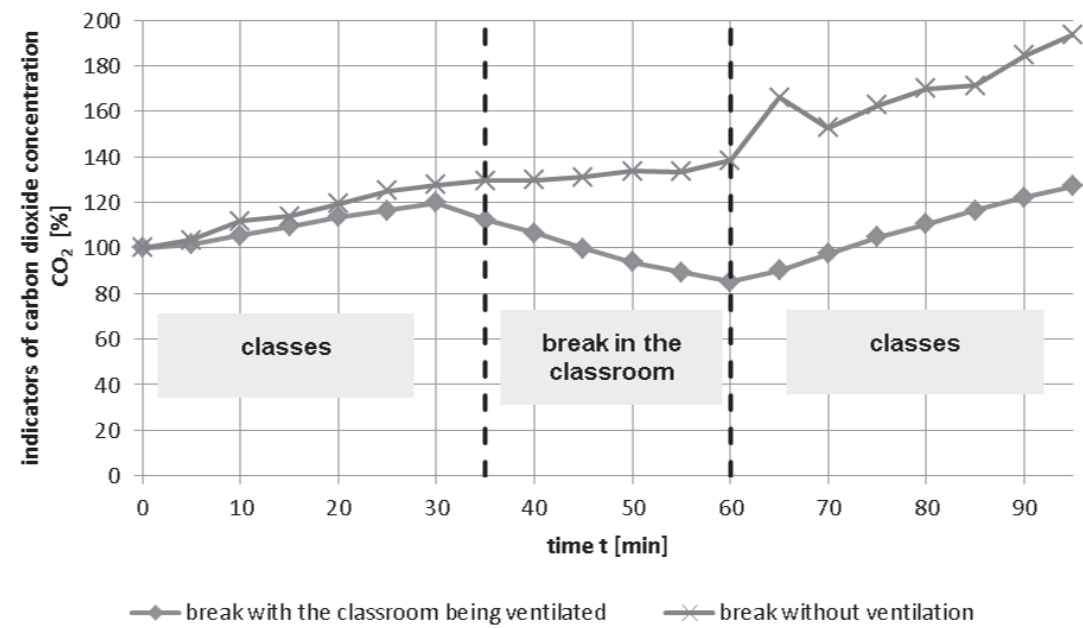

Fig. 2. Indicators of carbon dioxide concentration changes in the classroom during an experiment with ventilation of the classroom and without ventilation of the classroom during breaks.

$\mathrm{CO}_{2}$ concentration in classrooms were obtained in work [4].

Fig. 5 depicts the functions of concentration of $\mathrm{CO}_{2}$ depending on the time spent during classes for different volumes of rooms and numbers of students. A summary of the volumes of rooms and the number of students is given in Table 2. An analysis of the diagrams (Fig. 5) with data for several classes and breaks leads to the conclusion that in all classrooms the concentration of carbon dioxide increased. Ventilation of classrooms during breaks resulted in a drop of carbon dioxide concentration by about $25 \%$ (see Fig. 2, break with ventilation in time from $30 \mathrm{~min}$ to $60 \mathrm{~min}$ ). In the measurement series (Table 2) performed in classrooms that were ventilated during the breaks between classes, the carbon dioxide concentration function reaches its maximums at the end of the classes (before the breaks). During the classes, a linear increase of the concentration of carbon dioxide was observed, which could demonstrate poor efficiency of the stack ventilation (the concentration of carbon dioxide in all measurement series did not reach the stabilization point). The angle of inclination of the linear function of carbon dioxide concentration (Fig. 5) in relation to time depends most of all on the number of students in the classroom and its volume. The smaller the volume of the classroom and the smaller the number of students in it, the larger the angle of inclination between the $\mathrm{CO}_{2}$ concentration function curve and the time axis. In classrooms that are not ventilated between classes, the concentration of carbon dioxide during the breaks stabilized at a level equal to the value measured at the end of the class before the break (Fig. 2).

\section{Modelling Carbon Dioxide Content in Classrooms}

Our research demonstrated that the rate of increase of $\mathrm{CO}_{2}$ content in a classroom equipped with a stack ventilation system depends most of all on two parameters: the number of persons in the classroom and classroom volume. Based on the results of measurements that were performed, a model was prepared of the content of carbon dioxide as a function of time, depending on the volume of the classroom and the number of students:

$$
\mathrm{a}_{\mathrm{CO}_{2}}=\mathrm{B} \gamma t+\mathrm{a}_{\mathrm{CO}_{2}, t=0}, \quad \gamma=\frac{n}{V}
$$

...where $\mathrm{a}_{\mathrm{CO}}$, represents concentrations of $\mathrm{CO}_{2}(\mathrm{ppm}), \mathrm{t}$ is the time ( $\mathrm{min}), \mathrm{n}$ is the number of persons present in the classroom (person), $\mathrm{V}$ is the volume $\left(\mathrm{m}^{3}\right), \mathrm{B}=180$ is a constant factor $\left(\mathrm{m}^{3} \mathrm{ppm} /\right.$ person min), and $\mathrm{a}_{\mathrm{CO}_{2}, \mathrm{t}=0}$ is the initial concentration of $\mathrm{CO}_{2}(\mathrm{ppm})$.

The error of the $\mathrm{CO}_{2}$ model was determined using the following formula:

$$
\delta \mathrm{a}_{\mathrm{CO}_{2}}=\left|\frac{a_{\mathrm{CO}_{2}, \exp }-\mathrm{a}_{\mathrm{CO}_{2}}}{a_{\mathrm{CO}_{2}, \exp }}\right| 100 \%
$$

...where $\mathrm{a}_{\mathrm{CO}_{2} \text {,exp }}$ is the concentration of carbon dioxide measured in the classroom and $\mathrm{a}_{\mathrm{CO}_{2}}$ is the value of $\mathrm{CO}_{2}$ determined using Formula (1). The maximum average relative error of the individual measurement series did not exceed $10 \%$, while the average error in all the measurements is equal to $5 \%$. Formula (1) is functional for both classrooms ventilated and non-ventilated through open windows. Fig. 3 show a comparison of the numerical values (1) for the experiment with the unventilated classroom and with the ventilated classroom before class.

It should be emphasized that the elaborated model (1) can be used only in the case of classrooms with volume from about 200 to $420 \mathrm{~m}^{3}$. Coefficient $\gamma$ defines the relationship between the number of persons in the classroom and the cubage of the classroom. 


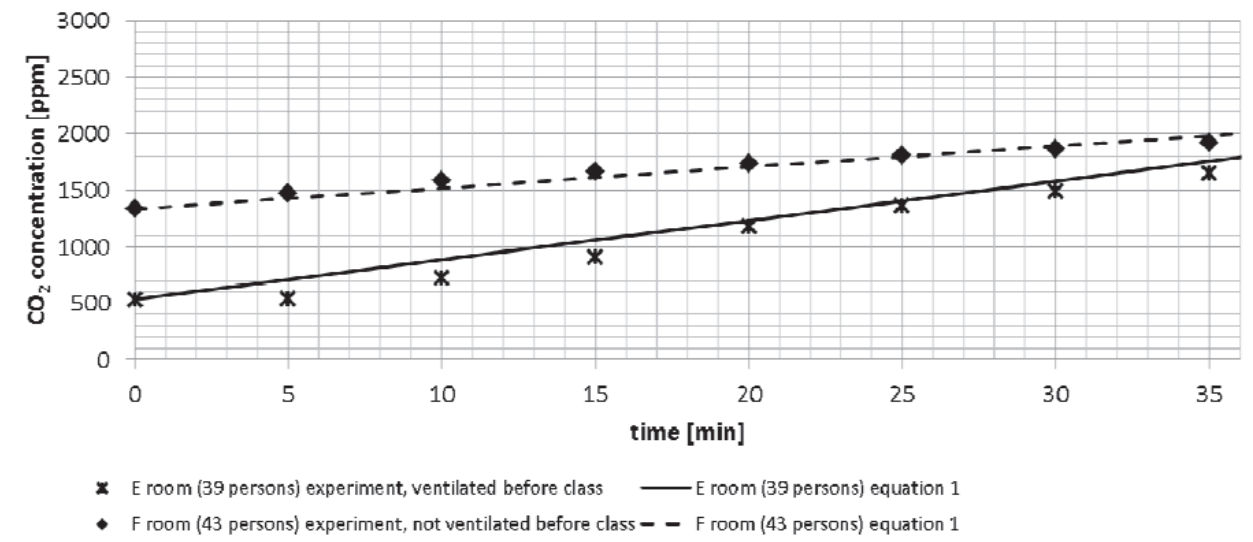

Fig. 3. A comparison between Formula (1) and the experimental values of $\mathrm{CO}_{2}$ concentrations in time in unventilated and ventilated classrooms before class.

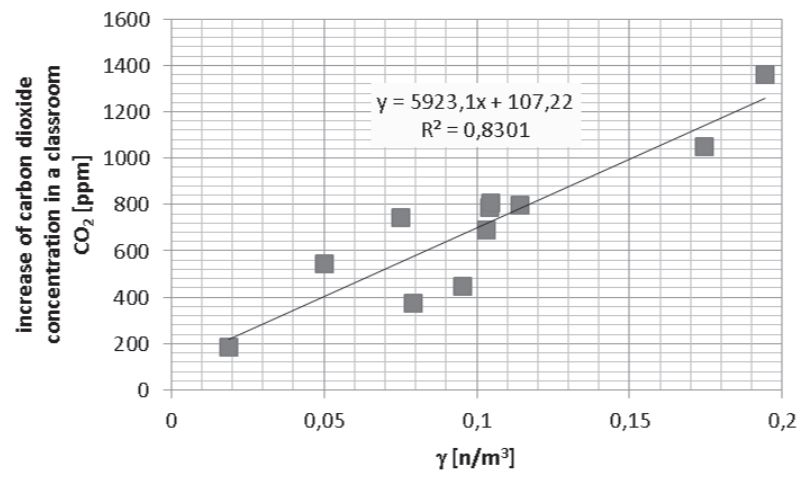

Fig. 4. The relationship between the increase of $\mathrm{CO}_{2}$ concentration in a classroom and the $\gamma$ coefficient.
Fig. 4 shows the relationship between the increase in the concentration of carbon dioxide in the classroom during classes and $\gamma$. This relationship can be approximated with a linear function with sufficient accuracy. The concentration of carbon dioxide in a classroom increases with an increase in the number of persons in the classroom and a reduction in the cubage of the classroom. The R2 determination coefficient is the measure of the model's fit. In the case of a relationship between the $\gamma$ coefficient and an increase in $\mathrm{CO}_{2}$ concentration in the classroom, it is equal to approx. 0.83 , which indicates a close linear relationship between the gamma coefficient and an increase of $\mathrm{CO}_{2}$ concentration (Fig. 4).

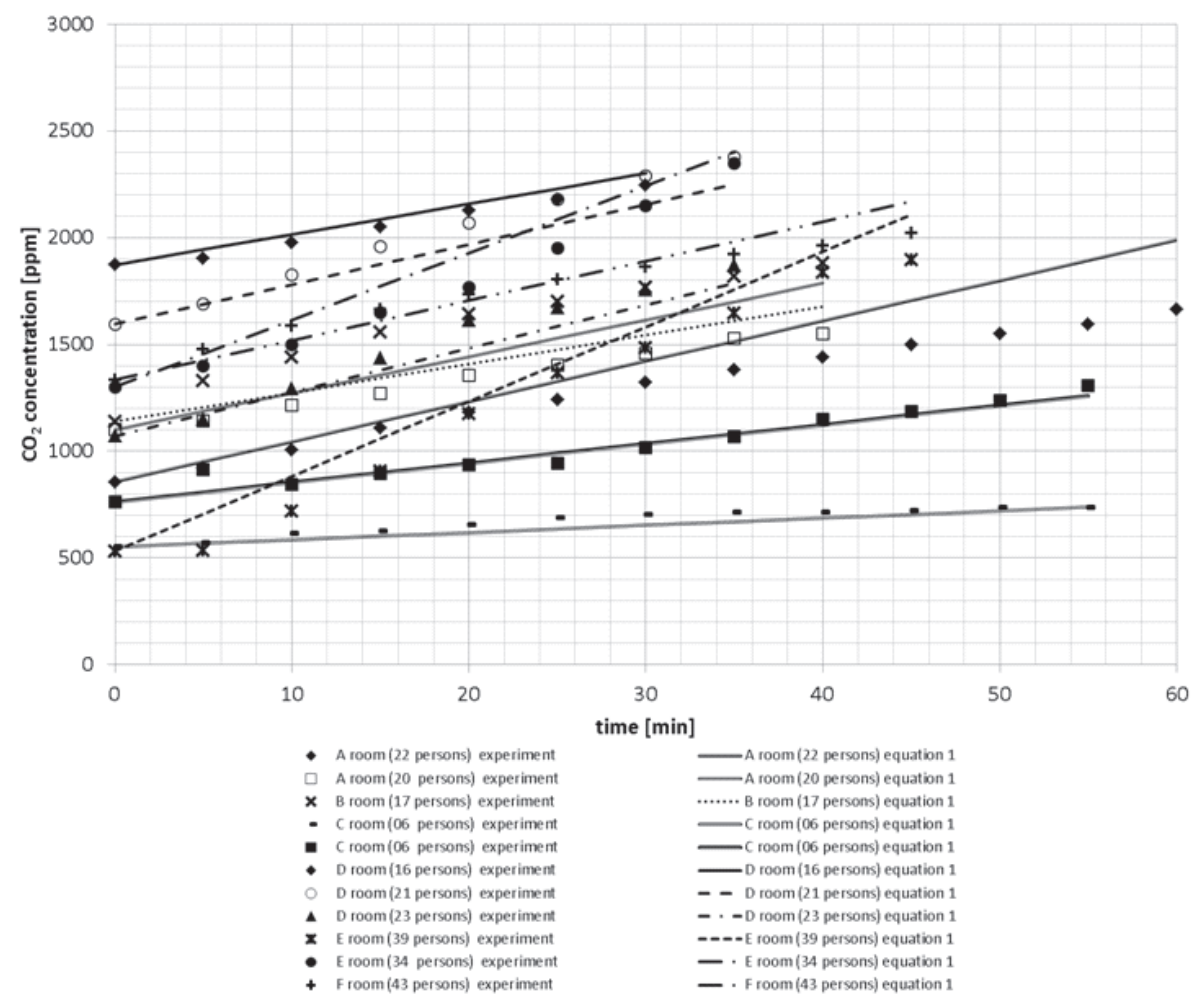

Fig. 5. Comparison of the measured values of carbon dioxide concentrations in classrooms with results obtained from Formula (1). 
Fig. 5 also shows a graphic comparison of formula (1) that defines the concentration of $\mathrm{CO}_{2}$ as a function of time in selected classrooms.

An analysis of the diagrams (Fig. 5) showing the relationship between carbon dioxide concentration and the duration of the classes leads to the conclusion that in all classroom there was a linear increase of carbon dioxide concentration, which may indicate poor efficiency of the stack ventilation (the concentration of carbon dioxide in none of the measurement series reached the stabilization point). The angle of inclination of the linear function of carbon dioxide concentration in relation to time depends most of all on the number of students in the classroom and its volume. The smaller the volume of the classroom and the smaller the number of students in it, the larger the angle of inclination between the $\mathrm{CO}_{2}$ concentration function curve and the time axis. What makes the diagrams different is also the vertical offset, which is due to the initial value of carbon dioxide concentration $\left(\mathrm{a}_{\mathrm{CO} 2}(\mathrm{t}=0)\right)$ in the classroom. In classrooms that were not ventilated through opening windows before class (e.g., No. D, Fig. 5), the vertical offset is much larger than in ventilated classes (e.g., No. C, Fig. 5). In classroom No. A, the results obtained using Formula (2) are much different than the results of the experiments. In this case, the maximum error obtained when using Formula (2) is as high as $19.5 \%$. Such a big difference between the results of the experiment and the elaborated model is probably due to the fact that the door of the classroom was opened several times.

The concentration of $\mathrm{CO}_{2}$ reached the maximum level of 2,347 ppm when the classroom was not ventilated before the measurement (the initial concentration was $1,738 \mathrm{ppm}$ ). The concentration of $\mathrm{CO}_{2}$ during other measurement series in all the classrooms where measurements were performed, in Poland, which has a temperate climate, reached a maximum level of 2,022 ppm.

\section{Conclusions}

The article presents a formula intended for forecasting concentrations of carbon dioxide in rooms equipped with stack ventilation and where carbon dioxide is produced by people. The model was verified based on the results of the research conducted in classrooms during classes. It was found that:

1) The concentration of carbon dioxide in the classroom increases throughout the duration of the classes (up to 2,300 ppm in classroom A).

2) In all measurement series, a linear increase in the concentration of carbon dioxide in the classrooms was observed (Fig. 5).

3) The rate of increase of carbon dioxide concentration depends most of all on the volume of the classroom and the number of students.
4) The classrooms naturally ventilated through open windows before classes can be classified as belonging to categories IDA1 and IDA2 (Table 1: 800-1,000 ppm; Fig. 5), while the classrooms not ventilated by open windows during breaks belong to categories IDA2 and IDA3 (Table 1: 1,000-1,400 ppm; Fig. 5) according to the standard PN-EN 13779: 2008.

5) Ventilation of classrooms results in a decrease in $\mathrm{CO}_{2}$ concentration in the classrooms during the break between classes, while lack of ventilation results in a stagnation of $\mathrm{CO}_{2}$ concentration. If windows are opened during breaks, the concentration of carbon dioxide in the classroom is significantly reduced.

In the future, tests will be conducted in airconditioned classrooms and the results will be compared to the results of the tests conducted in classrooms equipped with stack ventilation systems.

\section{Acknowledgements}

This study was executed with resources of the S/WBiIS/4/14 statutory work financed by the Ministry of Science and Higher Education in Poland, fellowships from the EU program "Increasing the potential of higher education as a factor of development based on knowledge," the Virtual and Intensive Course Developing Practical Skills of Future Engineers (VIPSKILLS) program of Erasmus+ (KA203), the "Possibility of renewable energy sources usage in the context of improving energy efficiency and air quality in buildings and civil constructions" program of scientific cooperation, and a project co-financed by the European Regional Development Fund under the Regional Operational Programme of the Podlaskie Voivodship for 2007-2013 (5.2 and 1.1).

\section{References}

1. ALMEIDA R.M.S.F., RAMOS N.M.M., DE FREITAS V.P. Thermal comfort models and pupils' perception in freerunning school buildings of a mild climate country. Energy Build. 111, 64, 2016.

2. ARENDT K., KRZACZEK M., TEJCHMAN J. Influence of input data on airflow network accuracy in residential buildings with natural wind- and stack-driven ventilation. Build. Simul. 10 (2), 229, 2017.

3. CETIN M., SEVIK H. Measuring the Impact of Selected Plants on Indoor $\mathrm{CO}_{2}$ Concentrations, Pol. J. Environ. Stud. 25 (3), 973, 2016.

4. DORIZAS P.V., ASSIMAKOPOULOS M.-N., HELMIS C., SANTAMOURIS M. An integrated evaluation study of the ventilation rate, the exposure and the indoor air quality in naturally ventilated classrooms in the Mediterranean region during spring. Sci. Total Environ. 502, 557, 2015.

5. SŁODCZYK E., SUSZANOWICZ D., Optimization of carbon dioxide concentration in the didactic rooms by the regulation of ventilation, Ecol. Chem. Eng. A 23, 275, 2016. 
6. KRAWCZYK D.A., GŁADYSZEWSKA-FIEDORUK K., RODERO A. The analysis of microclimate parameters in the classrooms located in different climate zones. Appl. Therm. Eng. 113, 1088, 2017.

7. KRAWCZYK D.A., RODERO A., GŁADYSZEWSKAFIEDORUK K., GAJEWSKI A. $\mathrm{CO}_{2}$ concentration in naturally ventilated classrooms located in different climates - measurements and simulations. Energy Build. 129, 491, 2016.

8. MAINKA A., BRĄGOSZEWSKA E., KOZIELSKA B., PASTUSZKA J.S., ZAJUSZ-ZUBEK E. Indoor air quality in urban nursery schools in Gliwice, Poland: Analysis of the case study. Atmos. Pollut. Res. 6, 1098, 2015.

9. MALINAUSKIENE V., LEISYTE P., MALINAUSKAS R., BAGDONAS G., JANKAUSKIENE L., MALINAUSKAITE I., Outdoor and Indoor Air Pollution and Myocardial Infarction among Women in Kaunas, Lithuania: a Case-Control Study, Pol. J. Environ. Stud. 20 (4), 969, 2011.

10. PEREIRA L.D., RAIMONDO D., CORGNATI S.P., DA SILVA M.G. Assessment of indoor air quality and thermal comfort in Portuguese secondary classrooms: Methodology and results. Build. Environ. 81, 69, 2014.

11. ASHRAE Standard 62-1989. Ventilation for acceptable Indoor Air Quality. Atlanta.

12. WHO 2000. Air Quality Guidelines for Europe. Second Edition 2000. WHO Regional Office for Europe Copenhagen. European Series. No. 91.

13. EN ISO 7730 (2005). Moderate Thermal Environment e Determination of the PMV and PPD Indices and Specification of the Conditions for Thermal Comfort.
International Organization for Standardization. Geneva. 2005.

14. BULIŃSKA A., POPIOŁEK Z., BULIŃSKI Z. Experimentally validated CFD analysis on sampling region determination of average indoor carbon dioxide concentration in occupied space. Build. Environ. 72, 319, 2014.

15. GLADYSZEWSKA-FIEDORUK K., RODERO A., Dependence of Carbon Dioxide Concentration and Relative Humidity in Didactic Room - Case Study. 20 (1), 17, 2017 [In Polish].

16. KOFFI J., EL MANKIBI M., GOURDON E., ISSOGLIO R. Assessment of single-sided ventilation with acoustic shutters on windows. Build. Simul. 8 (6), 689, 2015.

17. SHCHERBOVSKYKH S., SPODYNIUK N., STEFANOVYCH T., ZHELYKH V., SHEPITCHAK V., Development of a reliability model to analyze the causes of a poultry module failure, East. Eur. J. Enterprise Technol. 4 (3-82), 4, 2016.

18. PN-EN 13779: 2008. Ventilation of residential buildings. Requirements for the properties of ventilation and air conditioning.

19. http://freemeteo.pl/pogoda/bialystok/historia/codzienna-hi storia/?gid $=776069 \&$ station $=4155 \&$ date $=2016-07-06 \&$ lan guage $=$ polish \& country=poland $[11.11 .2016]$.

20. RECKNAGEL H., SPRENGER E., SCHRAMEK E.R. Taschenbuch für Heizung + Klimatechnik 07/08: Taschenbuch für Heizung + Klimatechnik 2007/2008. einschließlich Warmwasser- und Kältetechnik Gebundene Ausgabe - 27, 2006. 